\title{
Determination of Lead by Electrothermal Atomic Absorption Spectrometry Employing a Novel Sampling Strategy of Polyurethane Foam Impregnated with Thiazolylazo-p-cresol (TAC)
}

\author{
Otoniel D. Sant'Ana ${ }^{a}$, Luciene S. Jesuino ${ }^{a}$, Ricardo J. Cassella ${ }^{b}$, Marcelo S. Carvalho ${ }^{c}$ and \\ Ricardo E. Santelli*,a \\ ${ }^{a}$ Departamento de Geoquímica, Universidade Federal Fluminense, Outeiro de São João Batista s/n, Centro, \\ 24020-007 Niterói - RJ, Brazil \\ ${ }^{b}$ Departamento de Química Analítica, Universidade Federal Fluminense, Outeiro de São João Batista s/n, \\ Centro, 24020-007 Niterói - RJ, Brazil \\ ${ }^{c}$ Instituto de Engenharia Nuclear, CNEN-RJ, CP 68550, 21945-590 Rio de Janeiro - RJ, Brazil
}

\begin{abstract}
Este trabalho apresenta um método para a determinação de chumbo por ETAAS, baseado na amostragem sólida da espuma de poliuretano impregnada com o reagente 2-(2-tiazolilazo)- $p$-cresol (TAC) previamente utilizada para extrair o íon metálico da solução amostra. O processo de extração ocorreu em pH 10, tamponado com sistema borato, após 40 min de agitação das fases sólida e líquida. Os resultados obtidos mostraram a fácil eliminação da matriz do tubo de grafite, utilizando como pirólise a temperatura de $600{ }^{\circ} \mathrm{C}$, sem a adição de modificador químico de matriz. O método desenvolvido foi validado através da análise de materiais certificados de referência (amostras biológicas) e através de testes de recuperação em amostras salinas.
\end{abstract}

This work presents a method for lead determination by ETAAS, based on solid sampling of polyurethane foam (PUF) impregnated with the reagent 2-(2-thiazolylazo)-p-cresol (TAC) previously utilized to extract the metallic ion from sample solution. The extraction process occurred in a medium buffered in $\mathrm{pH} 10$ with borate system, after 40 min of agitation between the solid and liquid phases. The obtained results showed the easily elimination of the matrix from the graphite tube by a pyrolysis step at $600{ }^{\circ} \mathrm{C}$, without using of any matrix modifier. The method was validated by analysis of certified materials (biological samples) and by using recovery tests employing saline samples.

Keywords: solid phase extraction, polyurethane foam, thiazolylazo-p-cresol, solid sampling technique, lead, ETAAS

\section{Introduction}

Among various solid materials used in solid phase extraction (SPE), ${ }^{1-5}$ unloaded polyurethane foam (PUF) has been widely employed to extract many organic and inorganic species from different media. ${ }^{6-11}$ Also, PUF has been reported as a solid support for organic reagents in extraction processes of several species from aqueous solution. ${ }^{12-13}$ According to the literature,${ }^{14}$ this approach yields PUF-SPE procedures with higher selectivity and velocity.

The use of thiazolylazo compounds to load PUF has grown up in last few years, which has opened new possibilities for preconcentration/separation procedures.

*e-mail: santelli@geoq.uff.br
In this scenario, Cassella et al. reported the development of a flow system for cobalt preconcentration and determination by flame atomic absorption spectrometry using a minicolumn packed with PUF loaded with TAC (2(2-thiazolylazo)- $p$-cresol). ${ }^{15}$ Lemos and co-workers ${ }^{16,17}$ developed two procedures employing a BTAC (2-(2benzothiazolylazo)-2-p-cresol) loaded PUF minicolumn. In the first paper, ${ }^{16}$ an on-line method for cadmium determination in biological matrices was developed. In this case, a detection limit of $0.27 \mu \mathrm{g} \mathrm{L}^{-1}$ and an enrichment factor of 41 were obtained. In the other one, ${ }^{17}$ the on-line determination of lead in waters was performed achieving an enrichment factor of 26 and a detection limit of $1 \mu \mathrm{g} \mathrm{L}^{-1}$. In both cases, the detection was carried out by flame atomic absorption spectrometry. 
In a general way, the introduction of solid materials in ETAAS has been made employing different approaches: (i) direct introduction of the solid sample into the atomizer (including its injection in a form of a suspension) or (ii) introduction of a solid support containing the analyte immobilized $^{18-20}$ or coprecipitated ${ }^{21-22}$ with a suitable compound. When the last procedure is used, a previous sample pretreatment is required, increasing the possibilities of sample losses and contamination, making the procedure strongly dependent on the analyst skill. However, in this case very low detection limits might be achieved because a preconcentration step is carried out, besides a matrix simplification.

Recently de Sant'Ana et al. ${ }^{18}$ have used unloaded polyurethane foam for cobalt retention (as thiocyanate complex) and the introduction of the solid into the graphite furnace for Co determination in biological and saline samples. A detection limit of $80 \mathrm{pg} \mathrm{mL}^{-1}$ was achieved for a sample volume of $25 \mathrm{~mL}$ and $50 \mathrm{mg}$ of PUF. Takada and Koide ${ }^{19}$ employed an Amberlite IR-120B resin for copper sorption and determination in water samples. In this case, $6 \mathrm{mg}$ of loaded resin were inserted into the graphite furnace, which provided a characteristic concentration of $2 \mathrm{pg} \mathrm{mL}^{-1}$ for the method. As the same way, Shida and Matsuzaki ${ }^{20}$ used an anion-exchange resin (DIAION PA318) to sorb Ga as pyrocatechol violet complex. After extraction, the resin containing the analyte was filtered and a suitable mass was inserted into the graphite tube, yielding a detection limit of $3 \mathrm{pg} \mathrm{mL}^{-1}$ and a RSD of $5 \%$ (at $30 \mathrm{pg} \mathrm{mL}^{-1}$ ).

This work suggests the coupling between solid phase extraction with PUF to a direct solid introduction in ETAAS for lead determination, at trace level, in saline and biological samples. In order to achieve this goal, a PUF loaded with 2-(2-thiazolylazo)-p-cresol (TAC) was used for $\mathrm{Pb}$ (II) extraction.

\section{Experimental}

\section{Apparatus}

The samples were analyzed on a Hitachi polarized Zeeman atomic absorption spectrometer (Tokyo, Japan), model Z-8200, equipped with a cobalt hollow cathode lamp and an autosampler Hitachi model SSC-300. Integrated absorbance measurements were carried out using Hitachi Pyro tube-type cuvette. The instrumental operating conditions are summarized in Table 1. Suitable amounts of loaded PUF were weighed on a Perkin Elmer autobalance model AD-4.

\section{Reagents}

All reagents were of analytical grade and used without further purification. The solutions were always prepared with water purified in a Simplicity Milli-Q System (Millipore, Bedford, MA, USA).

Stock lead (II) solution of $1000 \mu \mathrm{g} \mathrm{mL}^{-1}$ was prepared from lead (II) nitrate (Merck, Darmstadt, Germany). Analytical solutions were daily prepared by adequate dilution of this solution before use.

A $0.5 \mathrm{~mol} \mathrm{~L}^{-1}$ borate buffer solution was prepared by dissolving $30.9 \mathrm{~g}$ of boric acid (Merck, Rio de Janeiro, Brazil) in around $800 \mathrm{~mL}$ water. Before diluting to exact $1000 \mathrm{~mL}$ the solution $\mathrm{pH}$ was adjusted to 10 with $1.0 \mathrm{~mol} \mathrm{~L}^{-1}$ $\mathrm{NaOH}$.

A $0.15 \% \mathrm{~m} / \mathrm{v}$ TAC solution was prepared by dissolving $0.75 \mathrm{~g}$ of 2-(2-thiazolylazo)-p-cresol (Merck, Darmstadt, Germany) in $500 \mathrm{~mL}$ of water containing $25 \mathrm{~g}$ of Triton $\mathrm{X}-100$.

A commercial open cell, polyether-type PUF (Vulcan of Brazil - COM 212 with $42 \%$ resilience and 10-12 cells/ linear $\mathrm{cm}$ ), was cut into small particles in a blender with purified water, sieved in a $1 \mathrm{~mm}$ pore plastic sieve and used as previously described. ${ }^{23}$

\section{General procedure}

The PUF was firstly plasticized by mixture of $5 \mathrm{~g}$ of foam with $10 \mathrm{~g}$ of tributyl phosphate (TBP) followed by vigorous stirring for $3 \mathrm{~h}$, according to Maloney et al.. ${ }^{24}$ Then, the foam was dried by heating at $70^{\circ} \mathrm{C}$ for about $3 \mathrm{~h}$. Then, $5 \mathrm{~g}$ of plasticized foam was added to $500 \mathrm{~mL}$ of TAC solution, agitated for one hour, filtered and dried at $70^{\circ} \mathrm{C}$ in an electrical furnace. After this, in order to eliminate the excess of TAC, the PUF was washed with $0.05 \mathrm{~mol} \mathrm{~L}^{-1}$ ammonium hydroxide solution and dried again at $70^{\circ} \mathrm{C}$ in an electrical furnace. The PUF obtained after these treatments was used as solid phase extractor.

The solid phase extraction procedure was carried out by mixing $100 \mathrm{mg}$ of dried PUF-TAC with $24 \mathrm{~mL}$ of sample containing $\mathrm{Pb}$ (II), between 1 and $10 \mu \mathrm{g} \mathrm{L}^{-1}$, and $1 \mathrm{~mL}$ of borate buffer. The mixture was agitated in a mechanical shaker during $40 \mathrm{~min}$. After elapsed the enough time to the system attain the equilibrium, the mixture was filtered (polyethylene filtration unit with $0.45 \mu \mathrm{m}$ pore size and $13 \mathrm{~mm}$ outer diameter, Millipore, Bedford, MA, USA) and the loaded PUF-TAC was washed with $0.05 \mathrm{~mol} \mathrm{~L}^{-1} \mathrm{NH}_{3}$ solution. Afterwards, the loaded PUF-TAC was dried at $70^{\circ} \mathrm{C}$ at an electric furnace and stored for posterior analysis.

For direct sample analysis by ETAAS, $0.50 \pm 0.02 \mathrm{mg}$ of dried PUF-TAC loaded with $\mathrm{Pb}$ (II) was transferred to the 
graphite atomizer. For this task, a suitable amount of PUFTAC was weighed in a bottom of a plastic tip (one of those used to transfer $100 \mu \mathrm{L}$ volume by pipette), which was cut at both ends, in order to allow PUF mass transfer to a graphite cuvette without losses. In order to deliver the amount of PUF into the cuvette, a $1.5 \mathrm{~mm}$ o.d. PTFE closed tube was used to push the foam. After the insertion of the solid phase into the graphite furnace, the temperature program (Table 1) was run and the integrated absorbance measured.

Table 1. Temperature program for lead determination after direct introduction of PUF-TAC loaded with $\mathrm{Pb}(\mathrm{II})$ into the graphite tube

\begin{tabular}{lcccc}
\hline Step & $\begin{array}{c}\text { Temperature } \\
\left({ }^{\circ} \mathrm{C}\right)\end{array}$ & $\begin{array}{c}\text { Ramp time } \\
(\mathrm{s})\end{array}$ & $\begin{array}{c}\text { Hold time } \\
(\mathrm{s})\end{array}$ & $\begin{array}{c}\text { Ar flow rate } \\
\left.(\mathrm{mL} \mathrm{min})^{-1}\right)\end{array}$ \\
\hline Drying & $140-300$ & 10 & - & 200 \\
Pyrolysis & 600 & - & 10 & 200 \\
Atomization & 2000 & - & 8 & 0 \\
Cleaning & 2200 & - & 4 & 200 \\
\hline
\end{tabular}

\section{Biological sample preparation}

The biological samples were prepared by closed vessel microwave-assisted acid dissolution using nitric acid (Merck, Darmstadt, Germany). First of all, the samples were dried overnight at $110 \pm 5^{\circ} \mathrm{C}$ in an electrical furnace. After cooling, an accurate mass of $0.7 \mathrm{~g}$ of TORT-2 (National Research Council of Canada) and $0.5 \mathrm{~g}$ of NIES $\mathrm{n}^{\mathrm{o}} 10 \mathrm{-c}$ (National Institute for Environmental Studies - Japan) was weighed into a polyfluoroethylene (PFA) liner suitable for use in microwave oven. Then, $10 \mathrm{~mL}$ of concentrated $\mathrm{HNO}_{3}$ were added to the flask and the mixture was stood for 1 hour to the initial destruction of organic matter. The mixture was taken to the pressurized microwave oven (maximum 200 psig), where it was irradiated for $10 \mathrm{~min}$ at $1000 \mathrm{~W}$ power. The solution obtained was clear and without suspended solids. In order to decrease the acidity of the medium, the solution was heated until dryness in a hotplate at $110{ }^{\circ} \mathrm{C}$ and the residue was dissolved in $2 \mathrm{~mL}$ of $0.1 \mathrm{~mol} \mathrm{~L}^{-1} \mathrm{HNO}_{3}$. Afterwards, $50 \mathrm{~mL}$ of purified water were added to the solution, followed by $4 \mathrm{~mL}$ of borate buffer solution and the volume was filled up to $100 \mathrm{~mL}$ with water. So that, an aliquot of $25 \mathrm{~mL}$ of the solution was agitated with $50 \mathrm{mg}$ of PUF-TAC for $40 \mathrm{~min}$ in a mechanical shaker.

\section{Saline samples and saline solutions preparation}

Saline samples of lagoon water (sampled from Lagoa Rodrigo de Freitas, Rio de Janeiro, Brazil) and seawater (sampled from Guanabara Bay, Rio de Janeiro, Brazil) were collected in polyethylene flasks. In order to avoid the adsorption of $\mathrm{Pb}$ (II) on flask walls, concentrated nitric acid was added to $\mathrm{pH}$ 1.5. No filtration of the samples was performed. Also, the acidified samples were maintained at $8^{\circ} \mathrm{C}$ until the analysis when $1 \mathrm{~mL}$ of borate buffer solution was added to $24 \mathrm{~mL}$ of each aliquot of water samples.

Besides saline water samples, synthetic sample solutions were prepared using different masses of three commercially available marine salts. They were directly dissolved in $10 \mathrm{~mL}$ of water, followed by addition of $1 \mathrm{~mL}$ of borate buffer solution and the volume filled up to $25 \mathrm{~mL}$ with water in order to obtain final concentrations of sodium chloride of 4,6 and $8 \% \mathrm{~m} / \mathrm{v}$, respectively (samples: $\mathrm{A}=$ $1.0 \mathrm{~g}, \mathrm{~B}=1.5 \mathrm{~g}$ and $\mathrm{C}=2.0 \mathrm{~g}$ ). To each of $25 \mathrm{~mL}$ of these samples (saline and synthetic sample solutions) $\mathrm{Pb}$ (II) solution was added to give analyte additions of 2 and $4 \mathrm{ng} \mathrm{mL} \mathrm{m}^{-1}$.

Afterwards, all solutions described above were agitated with $50 \mathrm{mg}$ of PUF-TAC for $40 \mathrm{~min}$ in a mechanical shaker.

\section{Results and Discussion}

In order to reach best conditions for retention of lead ion on the loaded PUF, all experiments were carried out by determining the concentration of $\mathrm{Pb}$ (II) remained in solution by ETAAS. Afterwards, the percentage of $\mathrm{Pb}(\mathrm{II})$ retained was derived from the following expression:

$\mathrm{Pb}(\mathrm{II})$ retained $(\%)=\frac{100\left(\mathrm{C}_{\mathrm{i}}-\mathrm{C}_{\mathrm{f}}\right)}{\mathrm{C}_{\mathrm{i}}}$

where $C_{i}$ and $C_{f}$ are the lead concentrations before and after the extraction process, respectively. These concentrations were determined by using the temperature program showed in Table 2. In each measurement an addition of $10 \mu \mathrm{g}$ Pd was done, as chemical modifier.

Table 2. Temperature program for lead determination in liquid samples

\begin{tabular}{lcccc}
\hline Step & $\begin{array}{c}\text { Temperature } \\
\left({ }^{\circ} \mathrm{C}\right)\end{array}$ & $\begin{array}{c}\text { Ramp time } \\
(\mathrm{s})\end{array}$ & $\begin{array}{c}\text { Hold time } \\
(\mathrm{s})\end{array}$ & $\begin{array}{c}\text { Ar flow rate } \\
\left(\mathrm{mL} \mathrm{m^{-1 } )}\right.\end{array}$ \\
\hline 1. Drying & $80-140$ & 30 & - & 200 \\
& 140 & - & 30 & 200 \\
2. Pyrolysis & 700 & - & 15 & 200 \\
3. Atomization & 1900 & - & 10 & 0 \\
4. Cleaning & 2100 & - & 4 & 200 \\
\hline
\end{tabular}

Characterization of the solid phase extraction of $\mathrm{Pb}(\mathrm{II})$ retention

The influence of medium $\mathrm{pH}$ on the retention of $\mathrm{Pb}(\mathrm{II})$ on the loaded PUF was evaluated in a range of 2 - 12. As 
can be seen in Figure 1, maximum sorption was obtained at $\mathrm{pH} 10$. It is well known that in $\mathrm{pH}$ higher than 10.5 , the water solubility of TAC is increased..$^{15}$ Therefore, the percentage of sorption of $\mathrm{Pb}$ (II) by TAC-loaded foam decreased in this condition, as result of the lower amount of the complexing reagent immobilized on foam. In consequence of this, all experiments were carried out employing borate buffer system at $\mathrm{pH} 10$.

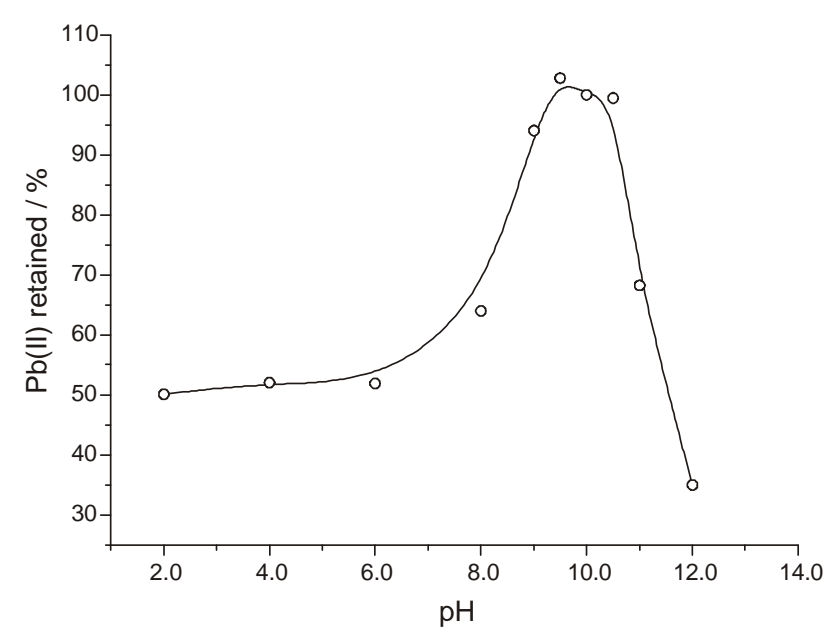

Figure 1. Effect of the $\mathrm{pH}$ on the retention of $\mathrm{Pb}(\mathrm{II})$ on PUF-TAC (25 mL $100 \mu \mathrm{g} \mathrm{L}^{-1} \mathrm{~Pb}$ agitated with $50 \mathrm{mg}$ EPU for $1 \mathrm{~h}$ ).

The evaluation of the time required for reaching the equilibrium between solid and liquid phases was carried out by agitating aliquots of $25 \mathrm{~mL}$ of solution, containing $100 \mu \mathrm{g} \mathrm{L}^{-1} \mathrm{~Pb}(\mathrm{II})$ in $\mathrm{pH} 10$, with $50 \mathrm{mg}$ of PUF between 0.5 and $120 \mathrm{~min}$. As can be seen in Figure 2, the quantitative extraction of $\mathrm{Pb}(\mathrm{II})$ was achieved after 40 min of shaking. This time was used for all further experiments.

The assessing of the sorption capacity of the solid phase was carried out by agitating, during $40 \mathrm{~min}, 25 \mathrm{~mL}$

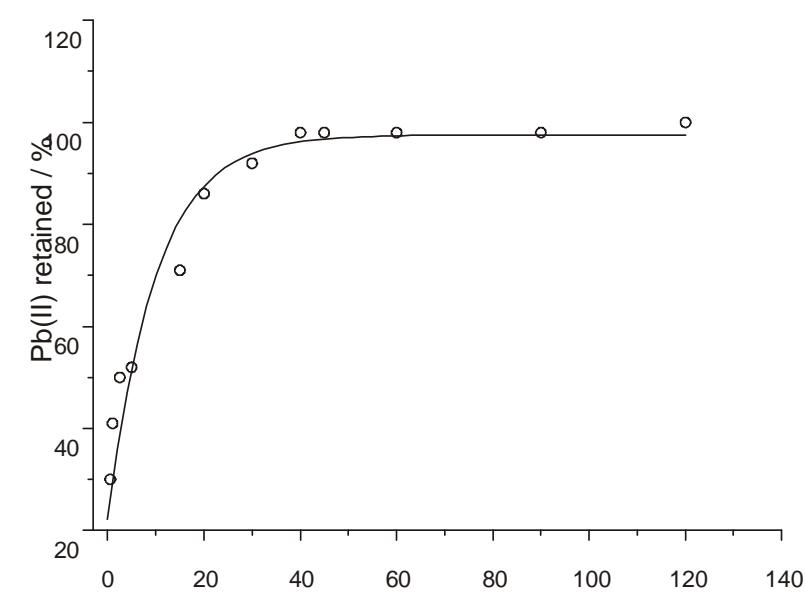

Figure 2. Effect of the shaking time on the retention of $\mathrm{Pb}(\mathrm{II})$ $\left(100 \mu \mathrm{g} \mathrm{L}^{-1}\right)$. PUF-TAC mass $=50 \mathrm{mg} ; \mathrm{pH}=10$. of solution containing $\mathrm{Pb}(\mathrm{II})$ between 0.1 and $10 \mathrm{mg} \mathrm{L}^{-1}$ with $50 \mathrm{mg}$ of PUF-TAC. The sorption data were subjected to the Langmuir isotherm according to the following form:

$\frac{\mathrm{C}_{\mathrm{e}}}{\mathrm{C}_{\mathrm{ads}}}=\frac{1}{\mathrm{Qb}}+\frac{\mathrm{C}_{\mathrm{e}}}{\mathrm{Q}}$

where $\mathrm{C}_{\mathrm{e}}$ is the concentration of the $\mathrm{Pb}$ (II) in the equilibrium (mol L-1); $\mathrm{C}_{\mathrm{ads}}$ is the sorbed concentration $\left(\mathrm{mol} \mathrm{g}^{-1}\right)$; $\mathrm{Q}$ is the Langmuir constant representing the maximum amount of $\mathrm{Pb}(\mathrm{II})$ retained on solid phase and; $b$ is a coefficient relating the affinity between $\mathrm{Pb}(\mathrm{II})$ and PUF-TAC. The plot of $\mathrm{C}_{\mathrm{e}} / \mathrm{C}_{\text {ads }}$ versus $\mathrm{C}_{\mathrm{e}}$ yielded a straight line, with linear correlation equal to 0.9995 , meaning that Langmuir sorption is followed by the sorption data very well. From the slope and intercept shown in Figure 3, the values of $\mathrm{Q}=1.81 \times 10^{-4} \mathrm{~mol} \mathrm{~g}^{-1}$ and $\mathrm{b}=2.01 \times 10^{7} \mathrm{~L} \mathrm{~mol}^{-1}$ were obtained.

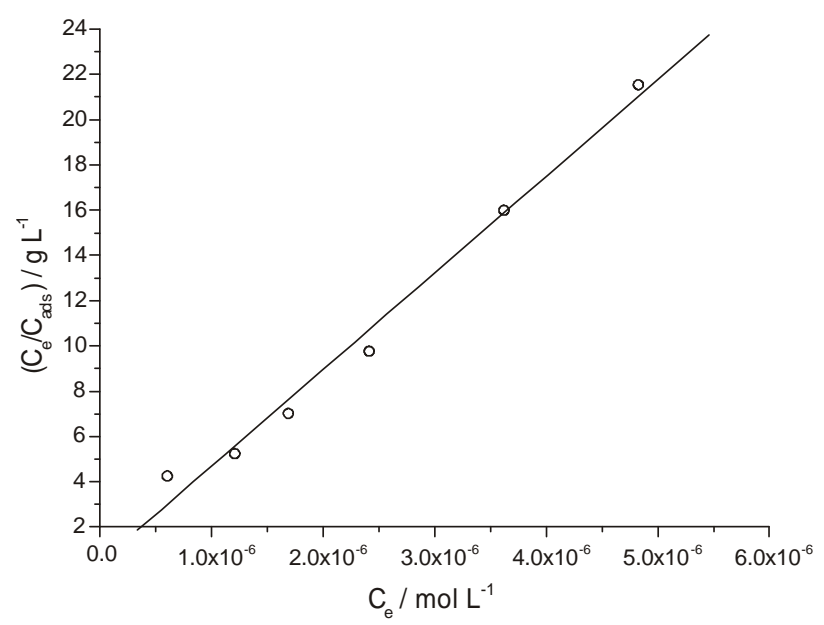

Figure 3. Langmuir isotherm applied to the sorption process of $\mathrm{Pb}(\mathrm{II})$ on PUF-TAC. PUF-TAC mass $=50 \mathrm{mg} ; \mathrm{pH}=10$; shaking time $=40 \mathrm{~min}$.

A thermodynamic characterization was performed evaluating the efficiency of the extraction of $\mathrm{Pb}$ (II) by $50 \mathrm{mg}$ PUF-TAC in different temperatures. The study consisted in the agitation, for $40 \mathrm{~min}$, of aliquots of $25 \mathrm{~mL}$ of solution containing $100 \mu \mathrm{g} \mathrm{L}^{-1} \mathrm{~Pb}$ (II) with $50 \mathrm{mg}$ of PUF-TAC between 28 and $52^{\circ} \mathrm{C}$. The equilibrium constant, $\mathrm{Kc}$, was calculated from the following equation:

$\mathrm{Kc}=\frac{\mathrm{F}_{\mathrm{e}}}{\left(1-\mathrm{F}_{\mathrm{e}}\right)}$

where $\mathrm{F}_{\mathrm{e}}$ is the fraction of $\mathrm{Pb}(\mathrm{II})$ sorbed at equilibrium. From this, $\log \mathrm{Kc}$ was plotted versus $1 / \mathrm{T}$ ( $\mathrm{T}$ in $\mathrm{K}$ ). As can be seen in Figure 4, a straight line was obtained over the entire range of temperature investigated. The following 
relationships were used to calculate the values of enthalpy, entropy and Gibbs free energy:

$\log \mathrm{K}_{\mathrm{c}}=-\frac{\Delta \mathrm{H}}{2.303 \mathrm{RT}}+\frac{\Delta \mathrm{S}}{2.303 \mathrm{R}}$

$\Delta \mathrm{G}=-\mathrm{RT} \ln \mathrm{K}_{\mathrm{c}}$

From the slope and intercept of the plot in Figure 4, the values of $\Delta \mathrm{G}, \Delta \mathrm{H}$ and $\Delta \mathrm{S}$ have been estimated respectively in $-7.61 \pm 0.17 \mathrm{KJ},-68.0 \pm 3.3 \mathrm{KJ}$ and $-202.7 \pm 10.5 \mathrm{~J}$. The negative values of $\Delta \mathrm{G}$ and $\Delta \mathrm{H}$ indicated, respectively, the spontaneous and exothermic character of the sorption of $\mathrm{Pb}$ (II) on PUF-TAC.

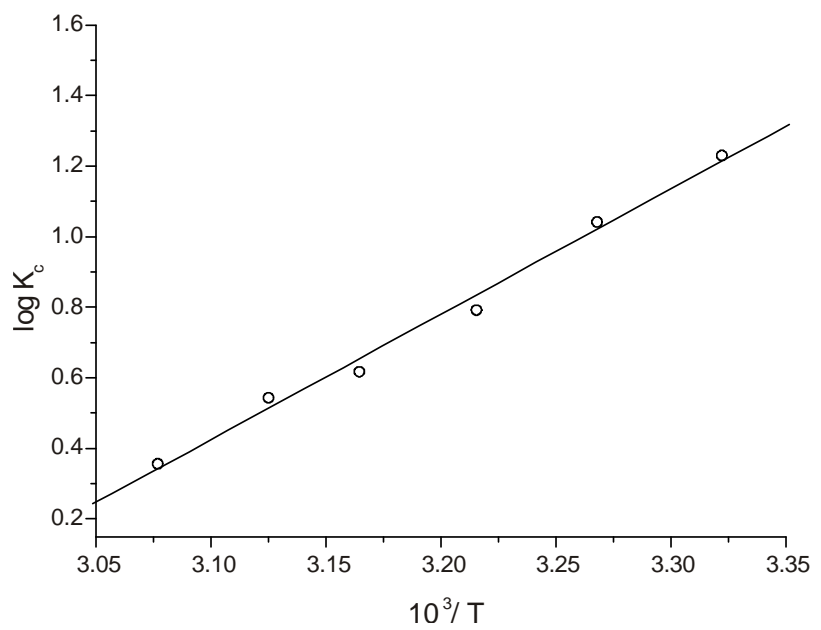

Figure 4. Effect of the temperature on the extraction of $\mathrm{Pb}(\mathrm{II})$ $\left(100 \mu \mathrm{g} \mathrm{L}^{-1}\right)$ by PUF-TAC. TAC mass $=50 \mathrm{mg} ; \mathrm{pH}=10$; shaking time $=40 \mathrm{~min}$.

\section{Solid sampling of PUF-TAC for Pb(II) determination}

Since the optimization of the pyrolysis and atomization steps in solid sampling in ETAAS are very important, these parameters were established by building up the respective curves. Pyrolysis temperature was tested between 200 and $1200{ }^{\circ} \mathrm{C}$ with a constant atomization temperature of $2000^{\circ} \mathrm{C}$. As can be seen in Figure 5, a significant reduction of the matrix was observed in $600{ }^{\circ} \mathrm{C}$, without losses of lead, being adopted this temperature as adequate for pyrolysis step. This observation confirms that the foam is totally eliminated in temperatures commonly used in the pyrolysis step. ${ }^{18}$

Although there was observed no significant difference in the integrated absorbance signals when atomization temperatures were varied from 1900 to $2200{ }^{\circ} \mathrm{C}$, poor repeatability were observed in temperatures above $2100^{\circ} \mathrm{C}$. Also, the absorption peak profiles obtained in

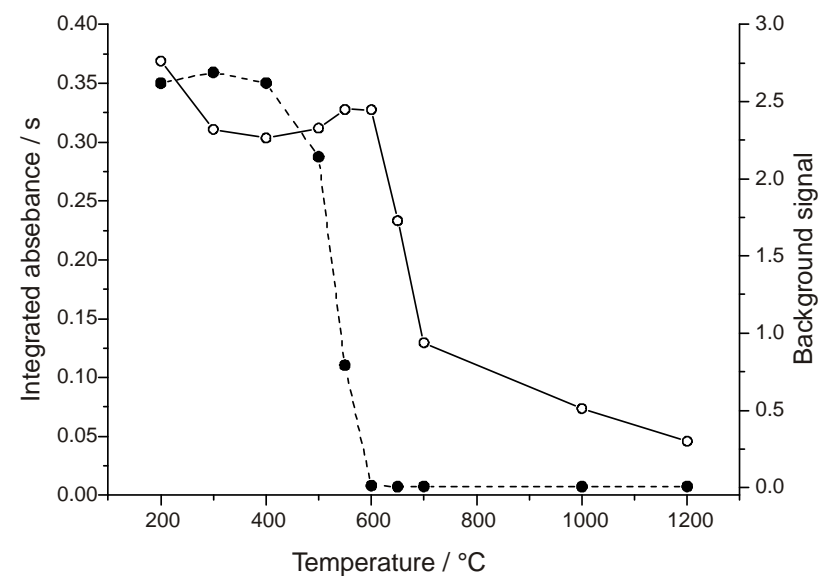

Figure 5. Pyrolysis curve obtained by the introduction of $50 \mathrm{mg}$ of PUF-TAC loaded with $\mathrm{Pb}(\mathrm{II})$ from a solution containing $100 \mu \mathrm{g} \mathrm{L}^{-1}$ $\mathrm{Pb}(\mathrm{II})$ : (@) background signal $(\mathrm{O})$ integrated absorbance.

$2000{ }^{\circ} \mathrm{C}$ were narrower than those observed in lower temperatures and they presented good repeatability. Therefore, this temperature was selected as atomization temperature.

As the loaded solid phase was previously dried, we thought that there was no need to carry out a drying step in the temperature program. However, a poor precision was verified when the measurements were done without the drying step, which probably occurred due to the splashed of the solid foam sample (PUF) inside the graphite tube during the fast heating in the pyrolysis step, making that $\mathrm{Pb}$ would be atomized from different parts of the tube. So that, a drying step with a $10 \mathrm{~s}$ ramp between 140 and $300^{\circ} \mathrm{C}$ was set on the temperature program. In fact this step was set on the temperature program in order to promote the total degradation of the foam before pyrolysis step and, then, the final temperature of $300^{\circ} \mathrm{C}$ was chosen because most of polyurethane foams can be degradated between 180 and $220^{\circ} \mathrm{C} .{ }^{25}$ This approach was successfully applied for the analysis of PUF impregnated with cobalt. ${ }^{18}$

Based on the quantitative extraction of $\mathrm{Pb}$ (II), it was possible to estimate the inserted analyte mass into the graphite tube. So that, calibration curves with aqueous standard solutions and with standards submitted to the same extraction process described in the general procedure were built up in order to compare the behaviour of $\mathrm{Pb}$ during atomization from water solutions and from foam. For aqueous standards, the same temperature program applied to the solid sampling was utilized, except by the different drying step with a ramp of 80 to $140^{\circ} \mathrm{C}$ in $30 \mathrm{~s}$ (Table 2). As a consequence of the different behavior of lead in aqueous solutions from solid matrix, the slopes obtained from each curve were different (aqueous standard: $\mathrm{y}=0.1971[\mathrm{~Pb}(\mathrm{ng})]-0.0017, \mathrm{r}=0.9991$; solid sampling: 
$\mathrm{y}=0.2511[\mathrm{~Pb}(\mathrm{ng})]+0.004, \mathrm{r}=0.9993)$. Better sensitivity of the solid sampling is probably due to the thermal stabilization of lead by PUF-TAC matrix, avoiding its volatilization in the pyrolysis step. The thermal changes on the crystalline nature of $\mathrm{Pb}\left(\mathrm{NO}_{3}\right)_{2}$ are responsible for the volatilization of $\mathrm{PbO}$ adsorbed on the walls of the graphite tube. According to Welz and Sperling ${ }^{26}$ the ratio of $\mathrm{PbO}: \mathrm{Pb}$ decreases when the concentration of lead present in solution is low. Considering that the most probable mechanism of lead atomization is related to the reduction of $\mathrm{PbO}$ by carbon from the surface of the graphite tube, some fraction of lead can be volatilized at low temperature. It could be favored the forming of $\mathrm{PbO}$ from PUF-TAC$\mathrm{Pb}$ (II) rather than $\mathrm{Pb}$ (II) from aqueous standard, yielding in this case more sensitivity to the solid sampling than the liquid sampling.

The influence of different PUF-TAC-Pb(II) masses inserted into the graphite tube was studied between 0.24 and $0.75 \mathrm{mg}$. For this task a foam containing $4 \mu \mathrm{g} \mathrm{g}^{-1}$ of $\mathrm{Pb}$ (II) was used. It was found a good correlation between the mass introduced and the signal as integrated absorbance $(r=0.9145)$ in the wide range tested $(40$ measurements), as can be seen in Figure 6.

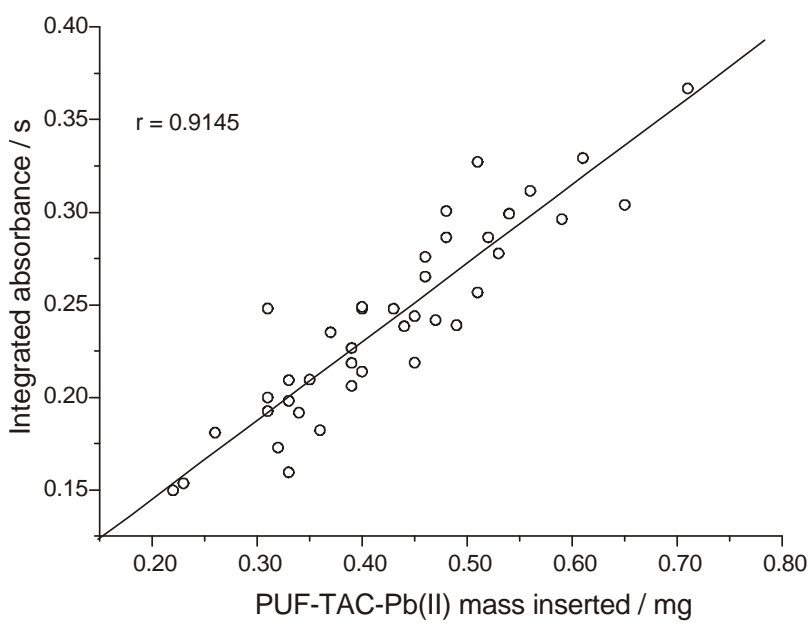

Figure 6. Effect of the introduction of different masses of PUF-TAC loaded with $\mathrm{Pb}(\mathrm{II})$ on the integrated absorbance of lead. $[\mathrm{Pb}]_{\text {PUF-TAC }}=$ $4 \mu \mathrm{g} \mathrm{g}^{-1}$.

Features of the proposed methodology and applications

With the proposed method, it was possible to obtain linear calibration graphs in the range of $0.25-2.0 \mathrm{ng}$ $\mathrm{Pb}$ (II) $\left(1-8 \mu \mathrm{g} \mathrm{L}^{-1} \mathrm{~Pb}(\mathrm{II})\right.$ in the aqueous solution), with a typical equation of $\mathrm{A}=0.251[\mathrm{~Pb}(\mathrm{ng})]+0.002$ and a correlation coefficient of 0.9993 , where A is the integrated absorbance and $[\mathrm{Pb}(\mathrm{ng})]$ is the lead mass in PUF-TAC in ng. The detection limit, calculated from three times the standard deviation of ten measurements of the PUF-TAC obtained from blank solution was $0.12 \mathrm{ng} \mathrm{Pb}\left(0.25 \mu \mathrm{g} \mathrm{L} \mathrm{L}^{-1}\right.$ $\mathrm{Pb}$ in the aqueous solution). The RSD, assessed by five measurements of the loaded foam from $1 \mathrm{mg} \mathrm{L}^{-1} \mathrm{~Pb}$ in the initial solution was found to be $10.4 \%$. In this condition a preconcentration factor of 16 was attained. ${ }^{27}$

The accuracy of the proposed methodology was checked by analyzing certified reference materials, lobster hepatopancreas TORT 2, furnished by the National Research Council of Canada (NRCC) and high cadmium content rice floor, № 10-c, furnished by the National Institute for Environmental Studies - Japan (NIES). As can be seen in Table 3, the obtained results were in good agreement with the certified values.

Table 3. Results obtained in the analysis of certified reference materials

\begin{tabular}{lcc}
\hline Sample & $\begin{array}{c}\text { Pb found } \\
\left(\mu \mathrm{g} \mathrm{g}^{-1}\right)\end{array}$ & $\begin{array}{c}\text { Pb reference values } \\
\left(\mu \mathrm{g} \mathrm{g}^{-1}\right)\end{array}$ \\
\hline TORT-2 & $0.36 \pm 0.02$ & 0.35 \\
NIES no $10 \mathrm{c}$ & $0.98 \pm 0.05$ & 1 \\
\hline
\end{tabular}

Recovery tests were carried out using sea water (Guanabara Bay), lagoon water (Rodrigo de Freitas Lagoon) and three different commercially available marine salts (sodium chloride), dissolved to obtain a final salt concentration of 4,6 and $8 \%(\mathrm{~m} / \mathrm{v})$ in $\mathrm{pH} 10$ adjusted by borate buffer solution. Good recoveries were obtained, as can be seen in Table 4. It is worth to mention that the saline solutions were analyzed by ETAAS. Palladium, as chemical modifier, was employed, being the matrix

Table 4. Results obtained in the analysis of spiked samples carried out with saline samples and saline solutions

\begin{tabular}{lcccc}
\hline Sample & $\begin{array}{c}\mathrm{Pb} \text { added } \\
\left(\mathrm{ng} \mathrm{mL}^{-1}\right)\end{array}$ & $\begin{array}{c}\mathrm{Pb} \text { found } \\
\left(\mathrm{ng} \mathrm{mL}^{-1}\right)\end{array}$ & $\begin{array}{c}\mathrm{Pb}^{(} \text {expected } \\
\left(\mathrm{ng} \mathrm{mL}^{-1}\right)\end{array}$ & $\begin{array}{c}\text { Error } \\
(\%)\end{array}$ \\
\hline Lagoon water & 0 & 0.45 & - & - \\
& 2.0 & 2.39 & 2.45 & -2.4 \\
Sea water & 4.0 & 4.40 & 4.45 & -1.1 \\
& 0 & 0.61 & - & - \\
& 2.0 & 2.54 & 2.61 & -2.7 \\
Salt A $^{a}$ & 4.0 & 4.58 & 4.61 & -0.6 \\
& 0 & 0.80 & - & - \\
& 2.0 & 2.75 & 2.80 & -1.8 \\
Salt B $^{a}$ & 4.0 & 4.54 & 4.80 & -5.4 \\
& 0 & 0.75 & - & - \\
& 2.0 & 2.81 & 2.75 & +2.2 \\
Salt $^{a}$ & 4.0 & 4.64 & 4.75 & -2.3 \\
& 0 & 0.92 & - & - \\
& 2.0 & 2.97 & 2.92 & +1.7 \\
& 4.0 & 4.80 & 4.92 & -2.4 \\
\hline
\end{tabular}

${ }^{a}$ Samples A, B and C were prepared by dissolving an enough amount of three different commercially available marine salts to obtain a final concentration of $\mathrm{A}=4 \% \mathrm{~m} / \mathrm{v}, \mathrm{B}=6 \% \mathrm{~m} / \mathrm{v}$ and $\mathrm{C}=8 \% \mathrm{~m} / \mathrm{v}$. 
eliminated at the pyrolysis step. Even though, it was impossible to measure the lead concentration because it was lower than the detection limit of the ETAAS technique.

\section{Conclusions}

The extraction process of $\mathrm{Pb}$ (II) by polyurethane foam loaded with 2-(2-thiazolylazo)-p-cresol was characterized physical and chemically before its analytical use for determine lead by solid sampling in ETAAS.

It was verified that the sorption capacity of the solid phase was limited by amount of TAC reagent physically immobilized on the foam surface. Although its relative low sorption capacity, the use of PUF-TAC showed to be suitable to the goal of this work.

The developed methodology exhibited an important alternative to the classical ETAAS procedures when a preconcentration step is mandatory. It was successfully applied to the analysis of biological samples and solutions containing high ionic concentration.

The main advantages of using the proposed methodology in relation to the conventional liquid sampling are the no needs of use chemical modifier, the matrix simplification and preconcentration, which permits that samples containing high salt concentration and low level of lead could be analyzed.

\section{Acknowledgements}

The authors are grateful to $\mathrm{CNPq}$ (Conselho Nacional de Desenvolvimento Científico e Tecnológico), CAPES (Coordenação de Aperfeiçoamento de Pessoal de Nível Superior) and FAPERJ (Fundação de Amparo à Pesquisa do Estado do Rio de Janeiro) for the grants and fellowships, and for financial support.

\section{References}

1. Singh, D.; Rawat, N. S.; Ind. J. Chem. Technol. 1997, 4, 39.

2. Wase, D. A. J.; Forster, C. F.; Biosorbents for Metal Ions, Taylor and Francis: London, 1997.

3. Tunçeli, A.; Tucker, A. R.; Talanta 2000, 51, 889.

4. Hiraide, M.; Iwasawa, J.; Kawaguchi, H.; Talanta 1997, 44, 231.

5. Grotti, M.; Abelmoschi, M. L.; Soggia, F.; Frache, R.; J. Anal. At. Spectrom. 2002, 17, 46.
6. Carvalho, M. S.; Domingues, M. L.; Mantovano, F. J. L.; Filho, E. Q. S.; Spectrochim. Acta, Part B 1998, 53, 1945.

7. Ferreira, S. L. C.; Lemos, V. A.; Costa, A. C. S.; de Jesus, D. S.; Carvalho, M. S.; J. Braz. Chem. Soc. 1998, 9, 151.

8. Drtil, M.; Tölgyessy, J.; Braun, T.; Fresenius J. Anal. Chem. 1995, 338, 291.

9. Alexandrova, A.; Arpadjan, S.; Anal. Chim. Acta 1995, 307, 71.

10. Aziz, P. W.; Beheir, S. G.; Shakir, K.; J. Radional. Nucl. Chem. 1993, 172, 319.

11. Hasany, S. M.; Saeed, M. M.; Ahmed, M.; Talanta 2001, 54, 89.

12. Halman, M.; Lee, D. W.; Anal. Chim. Acta 1980, 113, 383.

13. Braun, T.; Abbas, M. N.; Anal. Chim. Acta 1980, 119, 113.

14. Braun, T.; Navratil, J. D.; and Farag, A. B.; Polyurethane Foam Sorbents in Separation Science, CRC Press Inc.: Boca Raton, 1985.

15. Cassella, R. J.; Salim, V. A.; Jesuíno, L. S., Santelli, R. E.; Ferreira, S. L.C.; Carvalho, M. S. C.; Talanta 2001, 54, 61.

16. Lemos, V. A.; Santelli, R. E.; Carvalho, M. S.; Ferreira, S. L. C.; Spectrochim. Acta, Part B 2000, 55, 1497.

17. Lemos, V. A.; Ferreira, S. L. C.; Anal. Chim. Acta 2001, 441, 281.

18. de Sant`Ana, O. D.; Oliveira, L. G.; Jesuíno, L. S.; Carvalho, M. S.; Domingues, M. L. F.; Cassella, R. J.; Santelli, R. E.; J. Anal. At. Spectrom. 2002, 7, 258.

19. Takada, T.; Koide, T.; Anal. Chim. Acta 1987, 198, 303.

20. Shida, J.; Matsuzaki, S.; Anal. Sci. 1997, 13, 41.

21. Akatsuka, K.; Atsuya, I.; Anal. Chem. 1988, 329, 750.

22. Atsuya, I.; Itoh, K.; Fresenius'J. Anal. Chem. 1988, 329, 750.

23. Ferreira, S.L.C.; de Jesus, D.S.; Cassella, R.J.; Costa, A.C.S.; Carvalho, M.S.; Santelli, R.E.; Anal. Chim. Acta 1999, 378, 287.

24. Maloney, M. P.; Moody, G. J.; Thomas, J. D. R.; Analyst 1980, 105, 1087.

25. Braun, T.; Navratil, J. D.; Farag, A. B.; Polyurethane Foam Sorbents in Separation Science, CRC Press: Boca Raton, 1985.

26. Welz, B.; Sperling, M.; Atomic Absorption Spectrometry, Willey-VCH: New York, 1999.

27. Z. Fang; Flow Injection Separation and Preconcentration, VCH: Weinheim, 1993.

Received: March 28, 2003 Published on the web: January 19, 2004 